\title{
Industrial excess heat deliveries to Swedish district heating networks: Drop it like it's hot
}

\author{
Sarah Broberg, Sandra Backlund, Magnus Karlsson and Patrik Thollander
}

\section{Linköping University Post Print}

N.B.: When citing this work, cite the original article.

Original Publication:

Sarah Broberg, Sandra Backlund, Magnus Karlsson and Patrik Thollander, Industrial excess heat deliveries to Swedish district heating networks: Drop it like it's hot, 2012, Energy Policy, (51), 332-339.

http://dx.doi.org/10.1016/j.enpol.2012.08.031

Copyright: Elsevier

http://www.elsevier.com/

Postprint available at: Linköping University Electronic Press

http://urn.kb.se/resolve?urn=urn:nbn:se:liu:diva-86547 


\title{
Industrial excess heat deliveries to Swedish district heating networks:
}

\section{-Drop it like it's hot}

\author{
Sarah Broberg ${ }^{*}$, Sandra Backlund, Magnus Karlsson, Patrik Thollander \\ Department of Management and Engineering, Division of Energy Systems, Linköping University, Linköping, \\ Sweden \\ * Corresponding author. Tel.: +46 13281103 \\ E-mail address sarah.broberg@liu.se (S. Broberg)
}

\begin{abstract}
Using industrial excess heat in District Heating (DH) networks reduces the need for primary energy and is considered efficient resource use. The conditions of Swedish DH markets are under political discussion in the Third Party Access (TPA) proposal, which would facilitate the delivery of firms' industrial excess heat to $\mathrm{DH}$ networks. This paper estimates and discusses the untapped potential for excess heat deliveries to DH networks and considers whether the realization of this potential would be affected by altered DH market conditions. The results identify untapped potential for industrial excess heat deliveries, and calculations based on estimated investment costs and revenues indicate that realizing the TPA proposal could enable profitable excess heat investments.
\end{abstract}

Keywords: Excess heat, District heating, Third party access (TPA)

\section{Introduction}

Efficient use of resources and energy is central to the European Union's (EU's) strategy for "smart, sustainable and inclusive growth", a main target of which is to reduce primary energy use by $20 \%$ through implementing energy efficiency measures (EC, 2010). Large energy 
saving potential is estimated to exist in the industrial sector, realizable by implementing energy efficiency measures. How this energy saving potential can be realized is presented in European Commission (EC) directives. The latest proposed energy directive, the Energy Efficiency Directive (EED), was presented in June 2011 and is to replace the current Energy Service Directive (ESD) and the Combined Heat and Power (CHP) Directive. The EED raises the importance of using industrial excess heat, among other energy conservation measures (EC, 2011).

Excess heat is heat that industrial firms cannot use internally in production or support processes. Excess heat can be carried by either liquids or gases (SOU, 2005). The use of primary energy in heat production can be reduced by using industrial excess heat, which may confer both economic and environmental benefits. Studies have demonstrated that firms do not always use energy as cost efficiently as possible. Economic incentives to implement energy efficiency measures are not always enough, and discount rates for investment in energy efficiency are sometimes higher than for other investments of comparable risk. (DeCanio, 1998) Several methods are available to use excess heat, one of which is to deliver it to a District Heating (DH) grid. DH systems require large infrastructure investments. Welldeveloped DH systems can for example be found in northern European countries such as the Nordic countries (e.g., Sweden, Finland, and Denmark), Poland, and Germany. Sweden is also home to a large energy-intensive industrial sector, making industrial excess heat deliveries to DH networks interesting in the Swedish context.

A 2009 top-down investigation estimated the total potential for industrial excess heat delivery in Sweden to be $9 \mathrm{TWh} / \mathrm{year}$ (Cronholm et al., 2009). Previous studies have investigated the potential for excess heat deliveries and industrial cooperation with DH utilities, though bottom-up studies are lacking in the field. The conditions for excess heat deliveries to DH grids are under discussion. To create more efficient markets through competition, changing 
the ownership structure of DH systems has been proposed. A Third Party Access (TPA) proposal has been presented and is currently under political discussion. The outcome of this discussion may change the external regulatory and economic circumstances for firms delivering excess heat to DH grids.

This paper estimates the untapped potential for industrial excess heat deliveries and the economic incentives for excess heat use in DH grids in Sweden. Through a county case study the paper discusses the potential for industrial excess heat deliveries to DH networks in the studied counties, and considers whether the realization of this potential would be affected by altered conditions on DH markets.

\subsection{District heating in Sweden}

Sweden's first DH activity started in 1948 when industrial plants were connected to a central public heating system in Karlstad. In the 1950s, this effort was promoted by publicly owned DH utilities, but the great expansion began in the 1970s in response to the oil crisis. DH is now considered an energy-efficient way to heat e.g. buildings. As can be seen in Figure 1, DH deliveries have increased steadily in Sweden since the 1950s. The introduction of green

electricity certificates favoring electricity generation from biomass, which can fuel CHP plants, has made DH investments even more profitable. (SOU, 2011) The green electricity certificate is a market based policy instrument that gives extra revenues to renewable electricity production. A quota of renewable electricity production is set annually by the state and renewable electricity producer's gain certificates that are traded to for example producers that do not have renewable production. 


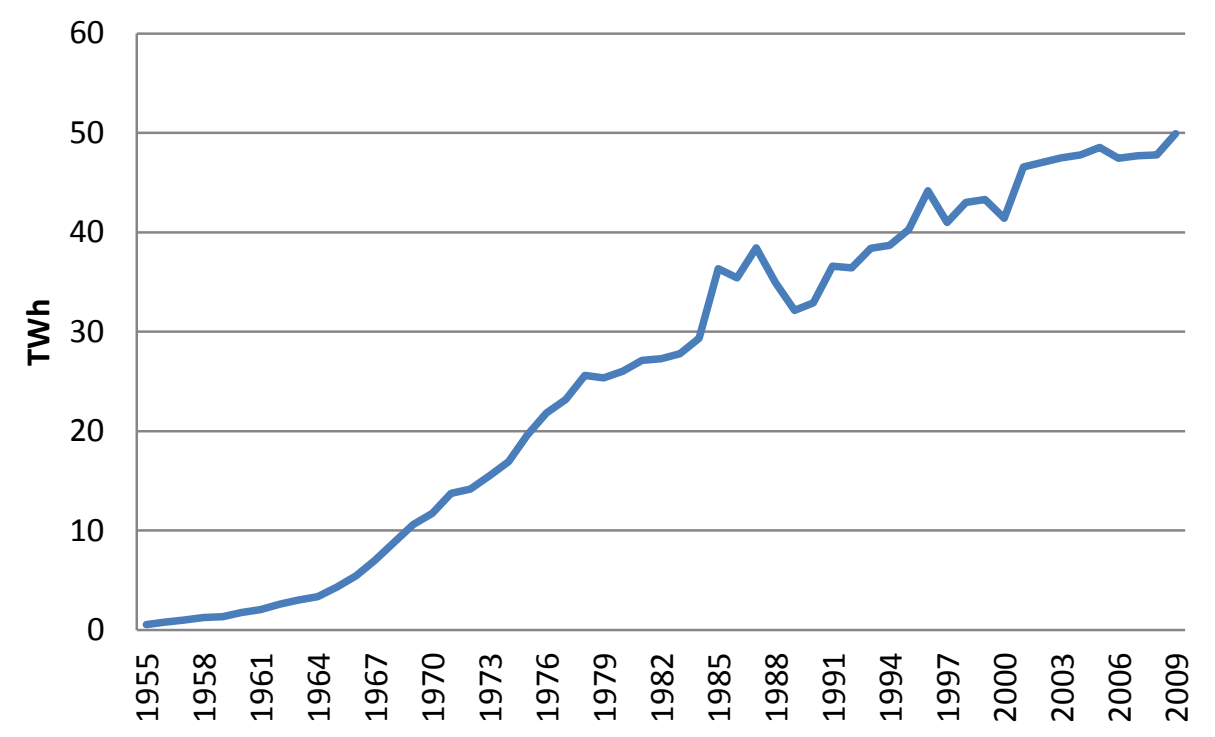

Figure 1. DH deliveries in Sweden (TWh/year), 1955-2009 (Statistics Sweden, 2012a).

DH consists of hot water, $65-120^{\circ} \mathrm{C}$, transported via pipes under a maximum pressure of 16 bars to customers connected to a DH grid. The DH market is comparable to those for natural gas and electricity in that it deals in energy transported via grids. There are currently $406 \mathrm{DH}$ grids in Sweden, and DH is the dominant heat source for buildings in urban areas ${ }^{1}$ in 253 of Sweden's 290 municipalities. DH grids are considered natural monopolies, as it is inefficient to have several competing grids. However, an important difference is that, while the gas and electricity markets are national, even international, DH can only be traded locally. (SOU, 2011)

DH water is mainly heated in heat or CHP plants or constitutes a byproduct of industrial processes in the form of excess heat. Figure 2 illustrates the energy and fuel mix supplied to DH networks in Sweden between 2005 and 2010. The use of biomass as a fuel is common in CHP plants, since it provides extra revenues due to the green electricity certificates. Over these years, the amount of energy produced for DH systems has increased by more than 50\%,

\footnotetext{
${ }^{1}$ Most buildings in urban areas are multi-family buildings, offices and large commercial buildings.
} 
while heat deliveries to customers have increased by less than $3 \%$. Electricity generation from CHP plants, which has increased by 42\%, accounts for the gap. (Statistics Sweden, 2012a)

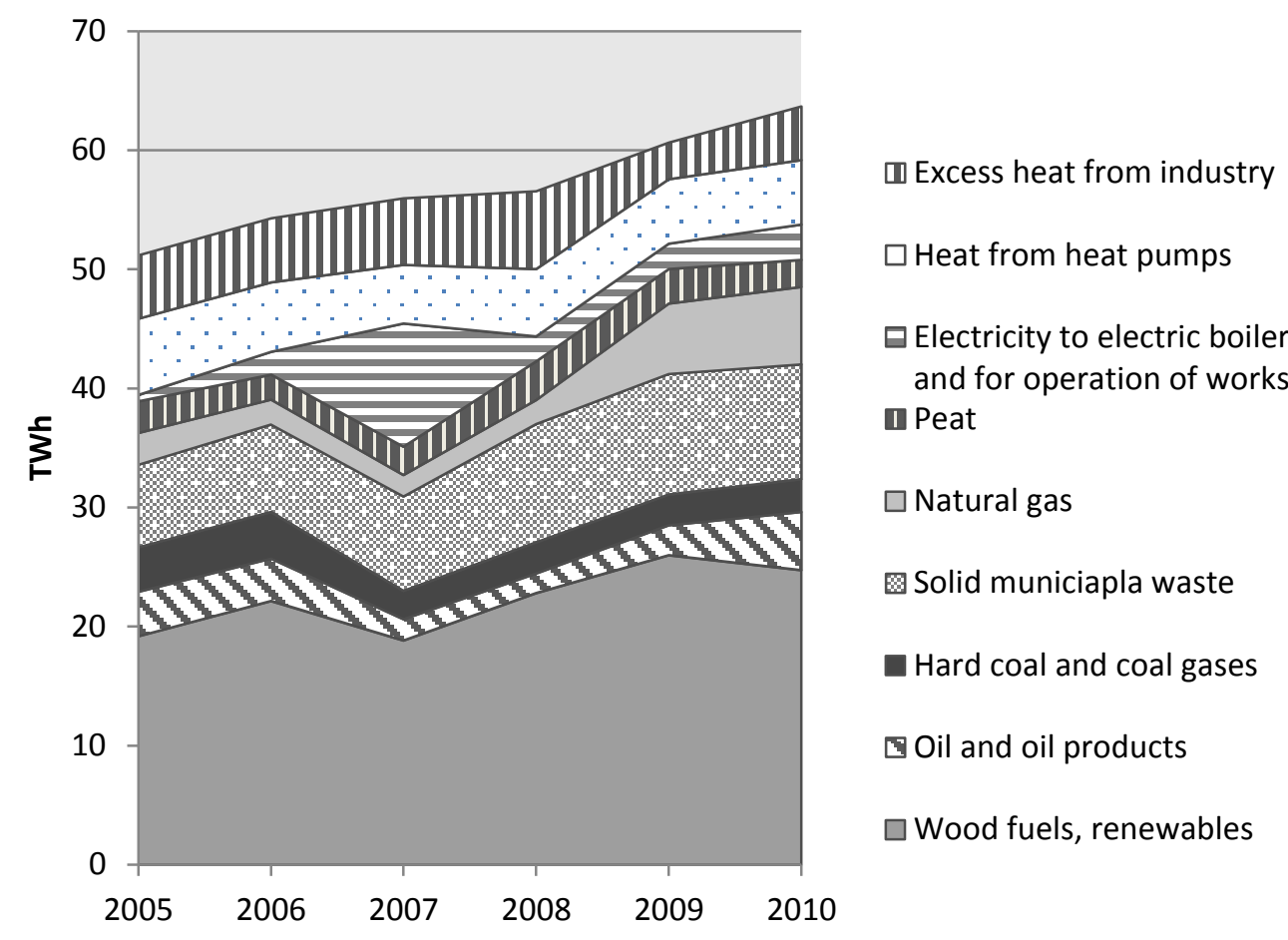

Figure 2. Energy and fuel mix supplied to the DH network in Sweden (TWh/year) (Statistics Sweden, 2012a). ${ }^{2}$

It is common for several production plants to be connected to a single $\mathrm{DH}$ grid. Often the companies that own the DH grids produce, distribute, and sell heat to the connected customers. These companies can be either private or publicly owned by municipalities. Since the deregulation of the electricity market in 1996, even public DH activities must be operated on a commercial basis. Producers that want to connect to a DH grid need to negotiate with the grid owner; these could be either heat plants or firms with excess heat. Grid owners are legally obliged to negotiate with actors that want to access the grid, but are entitled to deny access. Heat production in CHP plants enables electricity production, an additional source of

\footnotetext{
${ }^{2}$ The large increase in electricity use for DH production during 2007 was the result of very low electricity prices (yearly average of 30 EUR/MWh from the Nordic Spot Market (Nordpool, 2012)). The increased use of natural gas in the later years is due to new DH production based on Natural Gas Combined Cycle. The higher use of oil in 2010 was due to a very cold winter leading to higher use of oil for the smaller top load boiler units located near the energy end-users far from the central DH production plant.
} 
income for DH utilities, so it is not always in the grid owners' interest to allow other heat producers to connect to the grid. In addition excess heat competes with combustion of municipal waste. This means limited competition on the DH markets, as the grid owners determine the conditions for grid connection. Excess heat accounted for $6.7 \%$ of $\mathrm{DH}$ in Sweden in 2010, the main delivering firms being pulp and paper plants, chemical industry plants, steel firms, and foundries (SOU, 2011). Industrial excess heat is of two types: primary excess heat that can be delivered directly to a DH grid and secondary excess heat that must be upgraded before delivery (Grönkvist and Sandberg, 2006)

DH distribution (the actual grids) is considered a natural monopoly, but heat production is not. The aim of the TPA proposal is to help new heat producers access and compete on DH markets. The proposal would give all heat producers the right to access the grid. Markets in which actors want to access the DH grid will be divided into three parts: DH distribution (i.e., the grid owner), heat production, and companies selling heat (SOU, 2011). However, the TPA proposal has been criticized, two main objections being that it may raise DH costs by imposing administrative costs and that it may limit incentives to invest in new DH infrastructure (Ganslandt, 2011; Henning, 2011; Rydén et al., 2011; Swedish Waste Management, 2011).

\subsection{Previous studies of industrial excess heat delivery to DH grids and cooperation with DH} utilities

Previous studies of the potential for industrial excess heat use in the Swedish DH system have focused on cooperation with DH utilities.

Grönkvist and Sandberg (2006) investigated the driving forces of and obstacles to industrial plant cooperation with municipal DH utilities to deliver excess heat to $\mathrm{DH}$ grids and the 
circumstances under which such cooperation could occur. The sociotechnical analysis concluded that techno-economic factors were the main drivers of cooperation, but that the presence of people with the ambition to realize such cooperation was vital.

Svensson et al. (2008) developed an approach for investigating the factors that determine whether industrial excess heat is more profitably used internally or externally (i.e., delivered to a DH system). Their approach examined both techno-economic and environmental factors and consequences by modeling firm and DH utilities in the same energy system to explore the conditions for profitable cooperation. The sensitivity analysis explored the effects of fuel and electricity prices. Jönsson et al. (2008) used the same approach in investigating the potential for profitable excess heat cooperation by exploring four future energy market scenarios. The results indicated that profitability depends on energy market price, $\mathrm{DH}$ demand, and existing heat production in the DH network. External use, i.e., delivering excess heat to the DH grid, is profitable if industry cooperates with DH utilities with small heat loads.

Thollander et al. (2010) investigated factors that promote and inhibit DH collaboration between firms and DH utilities. The main conclusion was that human factors and the presence of specific individuals in the organizations involved in the collaboration are more important for success than are technological solutions.

\section{Method}

\subsection{Questionnaire}

One way to explore the amount of available industrial excess heat and the potential for using it is to visit industrial sites and perform energy audits. The same question can be investigated using questionnaires, allowing industrial firms to contribute their own data and estimates. Although this method is not as precise, it enables a larger sample. However, for energy 
intensive firms the energy flows are so complex that the firm's energy controller often have better information than can be obtained through an energy survey conducted by an external part.

In this multiple-county case study, a questionnaire was used to allow a large enough sample for generalizations to be made. The questionnaire was formulated by the Division of Energy Systems at Linköping University in cooperation with the county administrations of Östergötland and Örebro in Sweden. Östergötland and Örebro county were selected on the basis that these counties reflects Sweden as a whole in terms of Gross Regional Product (GRP) and energy-intensive industrial production (see Table 1). The web-based questionnaire was distributed by the two county administrative boards to the 85 largest companies located in Östergötland and Örebro counties in Sweden. For the geographic location of the counties, see Figure 3. In terms of GRP and value added by energy-intensive industrial production (see Table 1) the two studied counties are placed in the middle. Therefore it is assumed that industrial production in the studied counties is representative of Sweden as a whole and that general conclusions can therefore be drawn from these case studies.

Table 1 Production in Swedish counties, 2008 (Statistics Sweden, 2011b)

\begin{tabular}{lccc}
\hline County & $\begin{array}{c}\text { Gross regional } \\
\text { product (EUR, } \\
\text { millions) }\end{array}$ & $\begin{array}{c}\text { Value added from } \\
\text { energy intensive } \\
\text { industry (EUR, } \\
\text { millions) }\end{array}$ & $\begin{array}{c}\text { Percentage of } \\
\text { production from } \\
\text { energy intensive } \\
\text { industry }\end{array}$ \\
\hline Stockholm & 86508 & 2607 & 3 \\
Uppsala & 8981 & 793 & 0,9 \\
Södermanland & 7011 & 979 & 14 \\
\hline
\end{tabular}




\begin{tabular}{|c|c|c|c|}
\hline Östergötland & 11155 & 598 & 5,4 \\
\hline Jönköping & 9822 & 1009 & 10,3 \\
\hline Kronoberg & 5592 & 248 & 4,4 \\
\hline Kalmar & 6439 & 369 & 5,7 \\
\hline Gotland & 1375 & 11 & 0,8 \\
\hline Blekinge & 4036 & 148 & 3,7 \\
\hline Skåne & 33755 & 1915 & 5,7 \\
\hline Halland & 8236 & 497 & 6 \\
\hline Västra Götaland & 48178 & 2371 & 4,9 \\
\hline Värmland & 7155 & 708 & 9,9 \\
\hline Örebro & 7751 & 567 & 7,3 \\
\hline Västmanland & 6932 & 597 & 8,6 \\
\hline Dalarna & 8031 & 1086 & 13,5 \\
\hline Gävleborg & 7403 & 58 & 0,8 \\
\hline Västernorrland & 7226 & 41 & 0,6 \\
\hline Jämtland & 3635 & 22 & 0,6 \\
\hline Västerbotten & 7160 & 35 & 0,5 \\
\hline Norrbotten & 8371 & 39 & 0,5 \\
\hline
\end{tabular}


The companies were selected by the county administrative boards of Östergötland and Örebro and included energy-intensive companies and small enterprises with known high energy use. The selected firms operate in several areas, for example, the pulp and paper, chemical, steel, and concrete industries. There are several DH grids in both counties. The use of DH sums up to 2.9 TWh in Östergötland and 1.7 TWh in Örebro county. (Statistics Sweden 2012b) All regional and national statistics have been found on Statistics Sweden, the administrative agency coordinating the official Swedish statistics.

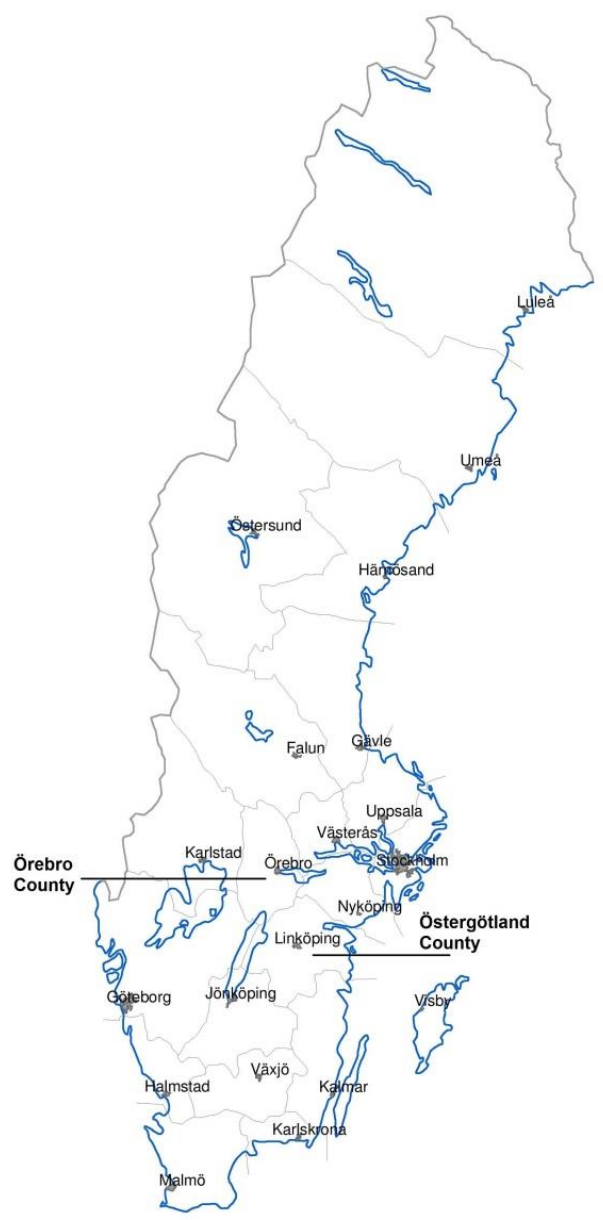

Figure 3. The studied counties, Östergötland and Örebro ㄷ Lantmäteriet 
The questionnaire consisted of three parts. The first part concerned the availability of excess heat and whether the possibility of using this heat internally and/or externally had been investigated. The second part addressed the amount of excess heat available in various energy carriers while the third part concerned firm energy management. Either the firms directly reported the excess heat potential or the flow and temperature were reported and the potential was calculated. Forty-three percent of the studied firms reported having estimated their excess heat potential, while the remaining firms' potential was calculated and/or measured (this was asked to get an idea of how precise the reported figures are). The firms were not required to complete all the questions to advance in the questionnaire, but could skip questions to which they did not have answers. Not all the questions addressed in the questionnaire will be discussed here.

The full questionnaire was complemented by a short version e-mailed to firms that had not completed the full version. The short version included questions from all three parts of the full questionnaire. In total, approximately $49 \%$ of the firms completed the questionnaire, $33 \%$ completing the full version and $16 \%$ the short version.

\subsection{Scenarios}

Forecasting future energy prices is complex but estimations are needed to evaluate future energy investment. One way to determine the future performance of firms delivering heat to DH networks is to use consistent scenarios; this has been done in this study to evaluate the outcome on different possible future energy markets. Energy market parameters are strongly interconnected and interdependent. Changes in supply and demand on one market will affect prices on all energy markets. The fossil fuel, electricity, bioenergy, and heat markets are all strongly interconnected, and their future prices will depend on policy instruments and possible energy conversion technologies. The ENPAC tool was used to estimate future long-term heat 
prices according to various scenarios by combining fossil fuel prices and $\mathrm{CO}_{2}$ charges. The scenarios give average yearly prices and vary greatly depending on the estimated input variables, the fossil fuel price and $\mathrm{CO}_{2}$ charge. For a full description of the tool and the scenarios and how they were arrived at, see Axelsson and Harvey (2010).

\section{Results}

\subsection{Industrial excess heat and potential deliveries to $\mathrm{DH}$ grids}

Energy use in the industrial and construction sectors in the studied counties totaled approximately 12.5 TWh in 2008 (Statistics Sweden, 2012a). In 2010, 149 TWh of energy was used in Sweden in the industrial sector (SEA, 2010), meaning that Östergötland and Örebro counties accounted for approximately $8.5 \%$ of Sweden's energy use in this sector. The firms completing the questionnaire reported total energy use of approximately $10.5 \mathrm{TWh} / \mathrm{year}$ in 2010. Relative to the total energy demand in the industrial sector in the region, this indicates that a large portion of the counties' industrial energy use is accounted for by the firms completing the questionnaire.

Several firms possess unused heat resources. Among the firms that completed the questionnaire, $60 \%$ declared that they have excess heat, though only $21 \%$ of the firms reported specific values for the amount of available excess heat in various energy carriers. This indicates a larger potential than reported in this study. The firms were asked to report the unused excess heat potential in the form of water, flue gases, air, steam, and byproducts. Due to low response rates and incomplete answers, only excess heat in the form of water, flue gases, and air will be considered here. 
There are DH grids in the two studied counties that already accept some industrial excess heat deliveries, totaling approximately 107 GWh in 2010 (Swedish District Heating Association, 2010). The reported untapped industrial excess heat potential in the two counties is illustrated in Figure $4 .^{3}$ The illustrated results are based on information from the firms that reported specific values. The graph shows the excess heat potential associated with each temperature level and heat carrier (i.e., water, flue gases and air). The heat presented is heat that is presently not used.

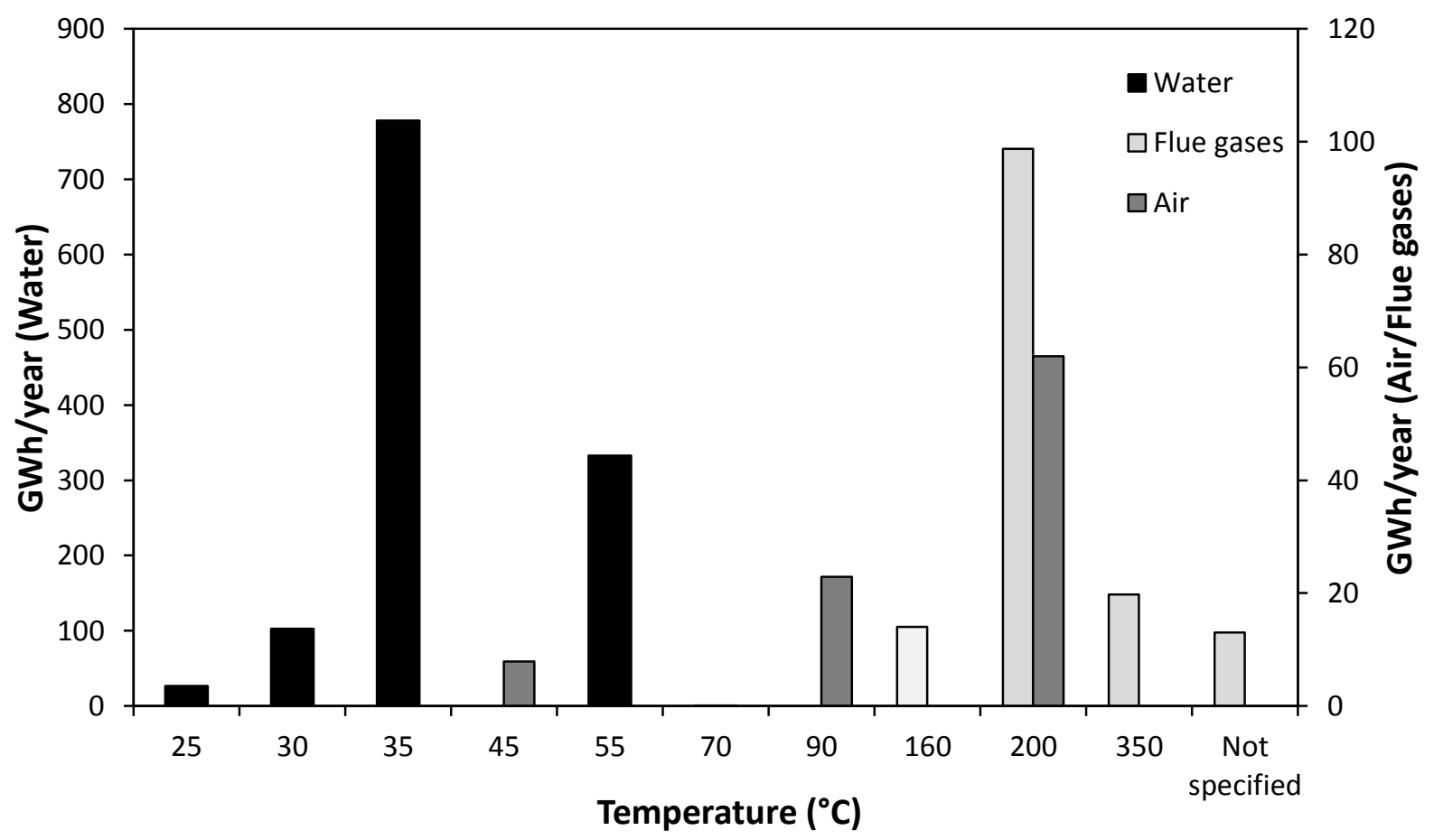

Figure 4. Industrial excess heat potential in Östergötland and Örebro counties for the three carriers: water, flue gases, and air.

Figure 4 shows that the largest potential is offered by hot water flows, but that these flows are low in temperature, ranging from $25-55^{\circ} \mathrm{C}$. Industrial excess heat at these low temperatures has somewhat limited application. The industrial excess heat potential independent of temperature and heat carrier totals approximately $1480 \mathrm{GWh} /$ year. This represents $14 \%$ of the

\footnotetext{
${ }^{3}$ The potential at $70^{\circ} \mathrm{C}$, representing the excess heat potential in water at this temperature, is $0.23 \mathrm{GWh} / \mathrm{year}$ and is therefore rounded to zero.
} 
energy input of the firms completing the questionnaire and $12 \%$ of the total energy used in the two counties in the industry and construction sectors. If this industrial excess heat, or part of it, were used, this could change the market conditions and fuel mix in the DH market.

Focusing on industrial excess heat deliveries to the DH network results in a particular temperature requirement on the industrial excess heat, so not all the available excess heat in the region is of interest in this study. Adding the requirement that the heat should fall within the definition of primary excess heat reduces the amount of suitable excess heat. In this multiple-county case study, the temperature requirement means that the industrial excess heat of interest comprises heat flows of $160-350^{\circ} \mathrm{C}$ (see Figure 4$){ }^{4}$

The excess heat in air that falls within the temperature range of interest will not be taken into account, since excess heat in the form of air should primarily be used internally due to large heat losses when heat from air is transferred to water. Five companies that possess excess heat in the studied counties fulfill the above temperature requirement; these firms will be referred to as companies $\mathrm{V}-\mathrm{Z}$.

Table 2 presents the firms possessing untapped excess heat potential for delivery to the DH grid, i.e., companies $\mathrm{V}-\mathrm{Z}$ and their excess heat delivery potential. The region's total potential for delivery to the $\mathrm{DH}$ grid is $146 \mathrm{GWh} /$ year, which corresponds to approximately $1.4 \%$ of the total energy supply in the companies completing the questionnaire.

\footnotetext{
${ }^{4}$ The potential when the temperature is not specified constitutes flue gas flow, which is assumed to be at a temperature within the primary excess heat range.
} 
Table 2 Firms with potential to deliver excess heat to the DH grid

\begin{tabular}{lcc}
\hline Company & Heat carrier & $\begin{array}{c}\text { Excess heat } \\
\text { potential } \\
\text { (GWh/year) }\end{array}$ \\
\hline $\mathrm{V}$ & Flue gases & 14 \\
$\mathrm{~W}$ & Flue gases & 13 \\
$\mathrm{X}$ & Flue gases & 28 \\
$\mathrm{Y}$ & Flue gases & 20 \\
$\mathrm{Z}$ & Flue gases & 71 \\
\hline Total potential: & $\mathbf{1 4 6}$ \\
\hline
\end{tabular}

\subsection{Excess heat use}

Four of the responding companies account for more than $80 \%$ of the total energy use reported in the questionnaire. Some of the firms report recovering excess heat internally. For example, heat is recovered internally to dry products and some of the firms use heat to generate electricity. However, heat that can be used internally, according to the previous definition of excess heat, does not classify as excess heat.

Among the companies that completed the full questionnaire, only $25 \%$ have investigated the possibility of delivering excess heat externally. Four of the companies' V-Z have contacted external parties such as DH utilities to discuss excess heat collaboration.

One studied firm already delivers excess heat to a $\mathrm{DH}$ grid, but it is worth noting that it is not one of firms $\mathrm{V}-\mathrm{Z}$. Twenty-one percent of the respondents report having explored the possibility of excess heat collaboration with the $\mathrm{DH}$ grid owner. In half of these cases, the 
grid owner declined the firms' suggestion. In the other cases, collaboration was not rejected, and the projects are still under discussion.

\subsection{Accounting for excess heat deliveries}

\subsubsection{Costs}

Determining the exact cost of connecting to a $\mathrm{DH}$ grid is impossible without a detailed project plan; however, the connection costs (e.g., for piping and excavation) can be roughly estimated. Though, connecting to a DH grid requires other, plant specific costs in addition to the connection costs, costs for piping and excavation are the only ones considered in these calculations. The investment cost per meter depends on the dimensions of the piping, which in turn are determined by the delivered power (W) and the ground conditions (e.g., urban area or development area) (Fredriksen and Werner, 2009). The estimated connection costs for companies $\mathrm{V}-\mathrm{Z}$ are listed in Table 3. Annual maintenance costs are approximately $1 \%$ of the investment costs (Fredriksen and Werner, 2009). The TPA proposal does not specify who will pay for maintaining the infrastructure, since production and distribution will be separated. Hence, once the investment is made, grid maintenance will probably not be the firms' responsibility.

Table 3 Companies V-Z: costs of connecting to the DH grid (Swedish District Heating Association, 2007).

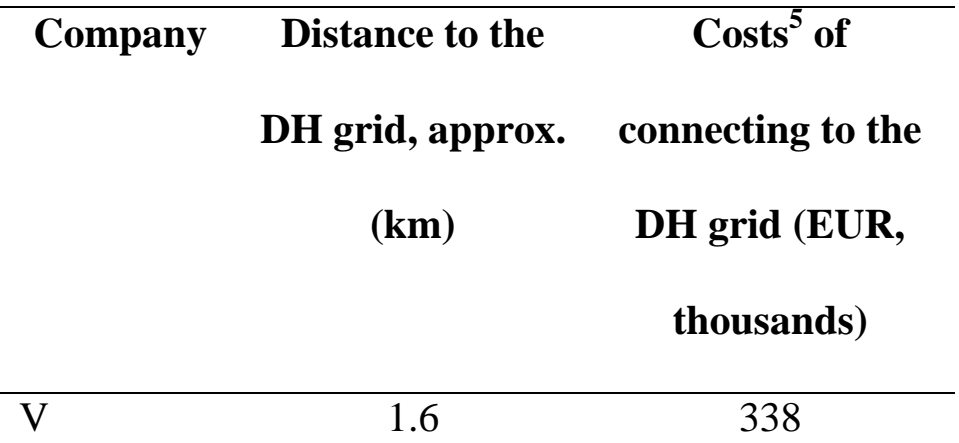

\footnotetext{
${ }^{5}$ Estimates for feed pipes are based on figures for development areas.
} 


\begin{tabular}{ccc}
$\mathrm{W}$ & 1.1 & 332 \\
$\mathrm{X}$ & 1.0 & 250 \\
$\mathrm{Y}$ & $<2.0$ & 500 \\
$\mathrm{Z}$ & 15.0 & 4667 \\
\hline
\end{tabular}

\subsubsection{Revenues}

Since DH markets are local, the price will differ between them. In a market with CHP plants on the margin, the price of heat will depend on the price of fuel, the electricity-to-heat ratio, CHP plant efficiency, operation and maintenance costs, the electricity price and $\mathrm{CO}_{2}$ emission charges. Given the fuel mix presented in Figure 2, the most expensive fuel on the margin in Swedish DH networks is coal (due to taxation and the European Union Emissions Trading Scheme), so the price of heat will depend on the price of coal. This is not true for all local DH markets but since energy markets are interconnected, the price of a different fuel (e.g. biomass) would differ but follow the same pattern. It is difficult to determine the future fuel mix in a DH grid, since the mix depends both on market developments in several energy markets and on policy instruments. This paper uses four scenarios to determine the heat price in 2020 (Axelsson and Harvey, 2010). The four chosen scenarios are presented in Figure $5^{6}$. The marginal production cost for heat is based on costs in a CHP while the marginal production cost for electricity is based on a power plant. The reason why the value for heat is lower in Scenario 1 than in Scenario 2 is because the revenues for electricity are higher in Scenario 1 . When the prices for fossil fuels are high, electricity becomes more expensive. The extra revenues from electricity generation allows for a lower heat price. Estimated revenues for companies $\mathrm{V}-\mathrm{Z}$, given the various price scenarios, are listed in Table 4.

\footnotetext{
${ }^{6}$ Input data for energy market scenarios:

Fossil fuel prices (EUR/MWh): low: 7.1, high: 8

$\mathrm{CO}_{2}$ charge (EUR/ton): low: 15, high: 52 (Axelsson and Harvey, 2010)
} 


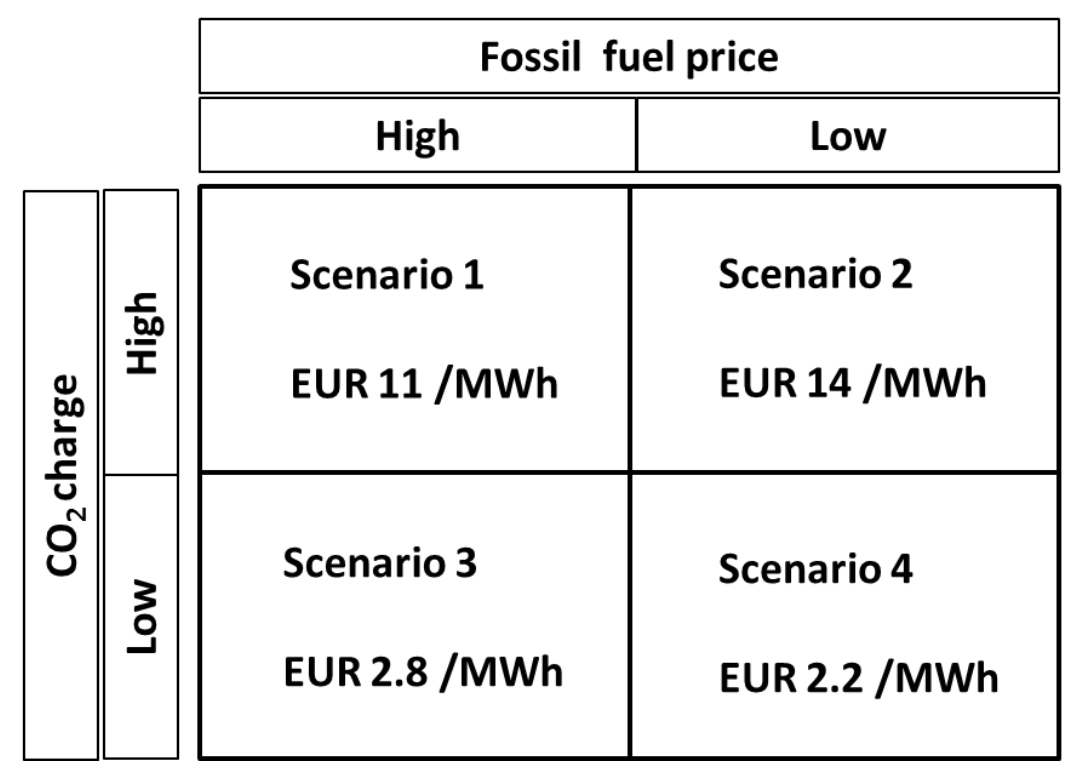

Figure 5. Projected market values of heat supplied to the DH network, $2020^{7}$

Table 4 Annual revenues for DH deliveries according to the four scenarios

\section{Revenues for DH deliveries (EUR thousands)}

\begin{tabular}{lcccc}
\hline Company & Scenario 1 & Scenario 2 & Scenario 3 & Scenario 4 \\
\hline V & 154 & 196 & 39 & 31 \\
W & 143 & 182 & 36 & 29 \\
X & 308 & 392 & 78 & 62 \\
Y & 220 & 280 & 56 & 44 \\
Z & 781 & 994 & 199 & 156 \\
\hline
\end{tabular}

\subsubsection{Profitability and pay-back}

Estimated investment costs and revenues make it possible to calculate the profitability of the investment needed to connect to the DH grids. The Net Present Value (NPV) has been calculated for the scenarios, and the results are presented in

\footnotetext{
${ }^{7}$ The reason why the value of heat is lower in Scenario 1 than in Scenario 2 is because the revenue for electricity is higher in Scenario 1. When the price for fossil fuels is high, electricity becomes more expensive. The fossil fuel prices have larger effect on electricity due to the different efficiencies in different plans.
} 
Table 5. Previous studies of DH investments have used a discount rate of 6\% (Fredriksen and Werner, 2009; Trygg and Amiri, 2006), and since the individual firms' discount rates are unknown, the same discount rate will be used here. An economic life of 20 years is assumed. The results indicate that for scenarios 1 and 2, the scenarios with the highest revenues, all NPVs are positive and hence the investment is profitable. For company Z, making the investment to connect to the grid means taking a risk, since the investment might not be profitable, depending on the market price of heat.

Table 5 Net present value of investment

\begin{tabular}{lcccc}
\hline \multicolumn{5}{c}{ Net present value of DH deliveries (EUR thousands) } \\
\hline Company & NPV & NPV & NPV & NPV \\
& Scenario 1 & Scenario 2 & Scenario 3 & Scenario 4 \\
\hline V & 1428 & 1910 & 109 & 17 \\
W & 1308 & 1756 & 81 & 1 \\
X & 3283 & 4246 & 645 & 46 \\
Y & 2023 & 2711 & 142 & 5 \\
Z & 4291 & 6734 & -2384 & -2878 \\
\hline
\end{tabular}

Profitability is important when making investment decisions, but not all profitable investments are made; other factors, such as energy strategies and pay-back criteria, also have a crucial impact. The mean time horizon for energy strategy in the studied firms is under three years which is similar to other study findings (Thollander and Ottosson 2010). Twenty-two percent of the firms lack an energy strategy altogether and almost one third of the firms has a strategy of five years or longer. Of the studied companies that reported pay-back criteria, $81 \%$ responded that they had a three-year pay-back term and 19\% a two-year term for investments 
in energy efficiency. Long-term energy strategies and pay-back criteria seem to be related, and all companies with long-term energy strategies reported three-year pay-back criteria.

Given the costs and revenues of companies $\mathrm{V}-\mathrm{Z}$, it is possible to calculate the pay-back for connecting to the DH grid. Even though not all costs are included, the pay-back gives a hint as to whether investments should be realized. The pay-backs for the chosen scenarios are listed in Table 6. Future energy market developments, i.e. the heat price, will have great impact on the pay-back time for the investments. Despite profitability, pay-back criteria can inhibit the investments.

Table 6 Pay-back for excess heat deliveries to the DH network (rounded to half a year).

Pay-back for investments needed to deliver excess heat (years)

\begin{tabular}{lccccc}
\hline Company & $\begin{array}{c}\text { Pay-back criteria } \\
\text { for investments in } \\
\text { energy efficiency }\end{array}$ & Scenario 1 & Scenario 2 & Scenario 3 & Scenario 4 \\
& 3 & 2 & 1.5 & 8.5 & \\
\hline V & 3 & 1.5 & 1.5 & 6.5 & 8 \\
W & - & 1 & 0.5 & 3 & 4 \\
X & 3 & 2.5 & 2 & 9 & 11.5 \\
Y & 3 & 6 & 4.5 & 23.5 & 30 \\
$Z$
\end{tabular}

\section{Concluding discussion}

This bottom-up county case study identifies considerable unused excess heat resources. Scaling up the results to a national level indicates unused primary heat potentials of approximately $2 \mathrm{TWh} /$ year and total unused heat potential (including secondary) of 21 
TWh/year ${ }^{8}$. The largest share of the heat is at lower temperatures, though there is still significant potential in the form of primary excess heat directly usable in DH grids. The economic review focused on primary excess heat, but this does not rule out deliveries of secondary heat to DH grids. The estimated theoretical industrial excess heat potential derived from the top-down study by Cronholm et al. (2009) of between 6.2 and $7.9 \mathrm{TWh} / \mathrm{year}$ lies inbetween these results. This can be explained by the fact that the former study has calculated the total potentials from current excess heat deliveries to DH grids. This implies that the study of 2009 has included parts of the secondary excess heat.

Using excess heat can reduce the need for primary energy, which in turn leads to economic gains and environmental benefits. Despite the large potential and well-developed DH networks, only a small share of the excess heat is being delivered to DH grids. It is therefore germane to discuss the underlying reasons why these resources are not being exploited.

The results of this study represent the outcome of assumptions made for calculations of excess heat potential, revenues, and costs. The calculated excess heat potential is based partly on estimated figures. The revenues are based on the estimated excess heat potential and the price of heat in the forecast energy market scenarios. The vast differences between the outcomes of the four scenarios indicate that it is difficult to forecast the future heat price and hence the revenues from investments in heat delivery infrastructure. It is also noteworthy that additional plant-specific costs will arise. The economic life of 20 years is low considering the nature of the investments, which underestimates their profitability. Despite these uncertainties, the study identifies untapped potential for profitable excess heat investments.

Companies V-Y all had positive NPVs for investments to deliver excess heat to DH grids, coal regardless of fossil fuel prices and $\mathrm{CO}_{2}$ charges. Realizing their reported potential of 75

\footnotetext{
${ }^{8}$ The potentials are calculated from the share of Swedish industrial energy use that is captured in this study and are based on the assumption that the excess heat potential in Östergötland and Örebro County are representative for the excess heat potential in Sweden as a whole.
} 
GWh/year would mean an increase of more than $70 \%$ in excess heat deliveries in the studied regions.

\subsection{Introducing TPA}

Previous studies of excess heat in Sweden have focused on cooperation between excess-heatproducing firms and DH utilities, because deliveries to DH grids currently must be approved by grid owners. To overcome this barrier, the TPA proposal suggests market changes. If the TPA proposal becomes a reality, cooperation will no longer be necessary: industrial excess heat will simply compete with heat produced in other plants.

The study found that few of the firms had investigated the possibility of delivering their excess heat to the DH grids. Of the firms that had explored this option and contacted the grid owners, half of the suggestions had been declined. Statistics on the Swedish DH market indicate that the amount of fuel used by heat plants has increased greatly over the last five years, despite a small increase in heat deliveries. This could be explained by the fact that DH is often produced in CHP plants and that electricity generation, which generates revenues, has increased. Industrial excess heat must thus compete with DH utilities' electricity generation in CHP plants.

With the realization of TPA, DH utilities will be unable to refuse industrial excess heat deliveries to the grid and it will be up to firms with excess heat resources to decide whether or not to connect to DH networks.

\subsection{Using potentials}

If the TPA proposal is realized, some DH production from CHP plants will be exposed to competition from industrial excess heat. As in all competitive markets, the price will be determined by the marginal cost of production, i.e., the most expensive unit on the margin 
will determine the market price. Excess heat is a by-product of industrial processes, so its marginal cost would be zero since the heat would be produced in any case. On a competitive market, the DH price will depend on the price of fuel on the margin. The price of fossil fuel and $\mathrm{CO}_{2}$ will affect the price of heat whether the marginal fuel is coal, biomass, or any other fuel. Therefore, the profitability of a $\mathrm{DH}$ investment depends on fossil fuel prices and $\mathrm{CO}_{2}$ charges.

In addition to profitability, other internal factors in the excess-heat-producing firms will determine whether or not DH deliveries are realized. Accessing DH grids requires large investments. Using scenarios to forecast the market price of heat, determine revenues, and estimate the investment cost of grid connections demonstrated that realizing excess heat potential was profitable in some cases. High $\mathrm{CO}_{2}$ charges have a large impact on profitability; another factor that affects profitability is the distance from the $\mathrm{DH}$ grid.

It should be noted that delivering industrial excess heat is not a core business for firms, so the required investments may not be prioritized. Companies that have short pay-back criteria can still benefit from the liberalization of $\mathrm{DH}$ markets, even if they do not want to invest themselves. Both current EU directives and the EED encourage member states to promote energy service markets. TPA permits a new kind of cooperation in which external companies, i.e., Energy Service COmpanies (ESCO), can finance strategic energy investments and split the profits with the firms supplying the industrial excess heat. This allows profitable energy investments to be made despite short pay-back criteria.

\subsection{Objections to TPA}

As previously discussed, TPA would open the market for heat deliveries to DH grids to competition. DH has so far been viewed as a natural monopoly, but the TPA proposal suggests making a division between heat production, distribution, and sales. This has been 
criticized by numerous stakeholders, who argue that there will be insufficient economic incentives to encourage new investments in $\mathrm{DH}$ infrastructure. This could inhibit $\mathrm{DH}$ development.

Another objection to increasing industrial excess heat use in DH grids is that it would replace heat from CHP plants, resulting in lower electricity generation. However, this replacement would release fuel resources that could then be used in alternative production, for example, for electricity generation in higher-efficiency power plants.

\section{Acknowledgements}

This work was carried out under the auspices on the Energy Systems Programme, funded primarily by the Swedish Energy Agency. The authors would like to thank the county administrations of Östergötland and Örebro. We would also like to thank our colleagues at the Department of Energy Systems for their valuable comments and input. Last but not least we would like to thank the reviewers for their help with improving the quality of the paper!

\section{References}

Axelsson, E., Harvey, S., 2010. Scenarios for Assessing Profitability and Carbon Balances of Energy Investments in Industry. AGS Pathways report 2010:EU1. The AGS, Göteborg, Sweden.

Cronholm, L.Å., Grönkvist, S., Saxe, M., 2009. Spillvärme från industrier och värmeåtervinning från lokaler. [Excess heat from industrial firms and heat recovery from premises] Report 2009:12. Svensk Fjärrvärme AB, Stockholm [In Swedish].

DeCanio, S., 1998. The efficiency paradox: bureaucratic and organizational barriers to profitable energy-saving investments. Energy Policy 26 (5), 441-454. 
European Commission (EC), 2010. Communication from the Commission, Europe 2020: A Strategy for Smart, Sustainable and Inclusive Growth. EC, Brussels.

European Commission (EC), 2011. Directive of the European Parliament and of the Council on Energy Efficiency 2011/1072 (COD). EC, Brussels.

Fredriksen, S., Werner, S., 2009. Fjärrvärme- teori, teknik och funktion. [District heating theory, technology and function] Studentlitteratur, Lund, Sweden [in Swedish].

Ganslandt, M., 2011. Ekonomiska konsekvenser av TPA-utredningens förslag. [Economic impacts of the TPA- investigation proposal] Center for European Law and Economics. [In Swedish].

Grönkvist, S., Sandberg, P., 2006. Driving forces and obstacles with regard to co-operation between municipal energy companies and process industries in Sweden. Energy Policy 34 (13), 1508-1519.

Henning, D., 2011. Tredjepartstillträde till fjärrvärmenäten: förslag och kritik. [Third Party Access to the DH grids: suggestions and criticism].Optensys Energianalys, Linköping, Sweden [In Swedish].

Jönsson, J., Svensson, I.L., Berntsson, T., Moshfegh, B., 2008. Excess heat from kraft pulp mills: trade-offs between internal and external use in the case of Sweden-part 2: results for future energy market scenarios. Energy Policy 36 (11), 4186-4197.

Nordpool, 2012., Swedish electricity spot prices. Available from: www.nordpool.no Rydén, B., Damsgaard, N., Sköldberg, H., Fritz, P., Stridsman, D., 2011. Konsekvensanalys av TPA, baserat på studier av verkliga fjärrvärmesystem. [Impact of TPA based on studies of actual DH systems] Profu and SWECO [In Swedish].

Statistics Sweden, 2012a. Energy. Available from: www.scb.se [In Swedish]. 
Statistics Sweden, 2012b. Regional Statistics. Available from: www.scb.se [In Swedish].

Swedish Energy Agency (SEA), 2011. Energy in Sweden 2011. Swedish Energy Agency Publication Department, Eskilstuna, Sweden.

SOU 2005:33 (Ministry of Enterprise Energy and Communications), 2005. Fjärrvärme och kraftvärme i framtiden, betänkande av fjärrvärmeutredningen. [DH and CHP in the future, reflections on the DH investigation ] Fritzes Offentliga Publikationer, Stockholm [In Swedish].

SOU 2011:44 (Ministry of Enterprise Energy and Communications), 2011. Fjärrvärme i konkurrens, betänkande av TPA-utredningen. [DH on competitive market, reflections on TPA] Fritzes Offentliga Publikationer, Stockholm [In Swedish].

Svensson, I.L., Jönsson, J., Berntsson, T., Moshfegh, B., 2008. Excess heat from kraft pulp mills: trade-offs between internal and external use in the case of Sweden - part 1: methodology. Energy Policy 36 (11), 4178-4185.

Swedish District Heating Association, 2007. Kulvertkatalog rapport 2007:1. [Pipe catalogue]. Swedish District Heating Association, Stockholm [In Swedish].

Swedish District Heating Association, 2010. Spillvärme 2010. [Excess heat 2010]. Swedish District Heating Association, Stockholm [In Swedish].

Swedish Waste Management, 2011. Remiss av TPA-utredningens betänkande Fjärrvärme i konkurrens. [Comments on the TPA investigations reflections on $\mathrm{DH}$ on a competitive market] [In Swedish].

Thollander, P., Svensson, I.L., Trygg, L., 2010. Analyzing variables for district heating collaborations between energy utilities and industries. Energy 35 (9), 3649-3656. 
Trygg, L., Amiri, S., 2006. European perspective on absorption cooling in a combined heat and power system: a case study of energy utility and industries in Sweden. Applied Energy 84 (12), 1319-1337. 